\title{
The Effect of Environmental Factors on the Abundance of Culturable Nitrate Reducing/Denitrifying Bacteria from Contaminated and Uncontaminated Tallgrass Prairie Soil
}

\author{
Samer M. AbuBakr ${ }^{*}$, Kathleen E. Duncan ${ }^{2}$, Greg Thoma ${ }^{3}$, and Kerry Sublette ${ }^{4}$ \\ ${ }^{1}$ Department of Biological Sciences, Fayetteville State University, Fayetteville, NC, 28301, USA; ${ }^{2}$ Depart- \\ ment of Microbiology and Plant Biology, University of Oklahoma, Norman, OK, 73019, USA; ${ }^{3}$ Department \\ of Chemical Engineering, University of Arkansas, Fayetteville, AR, 72701, USA; ${ }^{4}$ Department of Chemical \\ Engineering, University of Tulsa, Tulsa, OK 74104, USA
}

Received: January 16, 2019 / Accepted: March 2, 2019

\section{Abstract}

Various environmental factors have been proposed, such as soil moisture levels, carbon, and nitrate sources to affect the abundance of nitrate reducing (NR) and denitrifying (DN) bacteria. In this study, the strength of the association of the abundance of NR and DN bacteria with various environmental factors is estimated using multivariate statistical analysis. Soil samples were collected from tallgrass prairie soils that had been contaminated with crude oil or brine (e.g. salt water) up to $\mathbf{1 0}$ years previously and from parallel uncontaminated sites. The sites had been subjected to remediation shortly after contamination and also more recently (e.g. current remediation treatments). The abundance of culturable NR and DN bacteria in the soil samples was estimated by 5-tube MPN method using nitrate broth, while total petroleum hydrocarbons (TPH), sodium chloride, nitrate, and moisture were measured in the contaminated and the parallel uncontaminated sites. Viable heterotrophic bacteria and NR and DN bacteria ( $>10^{6} / \mathrm{g}$ soil) from all sites were obtained from samples with a broad range of soil moisture (from $10-30 \%$ water/g soil) regardless of the source (e.g. site) of the isolates. The abundance of NR and DN bacteria from the contaminated sites was not less than that from the uncontaminated sites. Although MPN values for heterotrophs and NR and DN bacteria were similar over a broad range of moisture levels, the relative abundance of NR and DN bacteria had a wide range (e.g. $0 \%$ to $100 \%$ ) in different samples with the same moisture level, which suggests that factors other than current levels of soil moisture controlled the \% NR and DN bacteria. Current remediation treatments of contaminated sites sometimes, but not consis tently, were associated with greater abundance of NR and DN bacteria (2-way ANOVA). Therefore, no long-term effect of contamination on the abundance of NR and DN bacteria was shown nor were current remediation treatments effective in stimulating the numbers of NR and DN bacteria.

Keywords: Nitrate reducing bacteria. Denitrifying bacteria, Soil moisture, Crude oil and brine contamination, Nitrogen.

\section{Introduction}

High levels of carbon, nitrate, and soil moisture (e.g. low oxygen concentration) are associated with higher denitrification rates when these environmental conditions occurred simultaneously (Groffman et al., 1993). In fact, it is not known whether these conditions favorable for denitrification persisted in formerly oil-contaminated sites and produced a greater abundance of NR and DN bacteria. However, it has been shown that denitrifying bacteria are not uniformly distributed in soils where the spatial heterogeneity of denitrification is influenced by spatial heterogeneity of carbon and $\mathrm{N}$ substrates in soils, and that denitrifying populations from select sites can be much greater than that indicated by MPN procedures of bulk soil (Murray et al., 1995; Martin et al., 1988; Harms et al., 2009).

The soil microbial community structure is thought to be one of the most sensitive indicators of biological properties of soil and reflects changes in the soil ecosystem (Kennedy and Smith, 1995; Yao et al., 2000). Different environmental factors, such as soil moisture, affect microbial activities and composition in soil

\footnotetext{
"Corresponding author: sabubakr@uncfsu.edu
}

This is an Open Access article distributed under the terms of the Creative Commons Attribution License (http://creativecommons.org/licenses/by/3.0/), which permits unrestricted use, distribution, and reproduction in any medium, provided the original work is properly cited. 
by affecting the physiological status of bacteria (Harris, 1981). In fact, the osmotic status of bacterial cells is affected by water availability that can regulate diffusion of gases, substrate accessibility, soil temperature, and $\mathrm{pH}$. Moreover, moisture shortage may affect bacterial communities by stressing plants. Drought causes changes in nutrient distribution below ground and the release of organic compounds from plant roots into soils (Lynch and Whipps, 1990). Periods of moisture limitation may be a strong selective pressure on the structure and functioning of soil bacterial communities. Also, it has been shown that soil moisture is involved in controlling fluxes of important greenhouse gases such as nitrous oxide, even if these fluxes are not totally the result of microbial activity (Bollmann and Conrad, 1998). Sublette et al. (2007a) found that soil moisture had a strong influence on viable biomass of soil microbes when phospholipid fatty acid (PLFA) concentrations from tallgrass prairie soil samples were measured. The PLFA concentration reflects the viable microbial biomass (White et al., 1997).

Soil moisture also impacts NR and DN bacteria by controlling oxygen diffusion to sites of microbial activity. When the moisture levels increases up to $60 \%$ of moisture holding capacity, the number of most microorganisms increase. However, when soil moisture increases to more than $60 \%$ of moisture holding capacity, oxygen diffusion and availability to microbes will decrease. As a result, facultative anaerobic microorganisms will be stimulated to use alternative electron acceptors such as nitrate. These conditions are expected to increase the number of NR and DN bacteria with respect to that of strict aerobes, if these low oxygen conditions are maintained and nitrate is available (Paul and Clark, 1989). However, soil moisture is not the only environmental factor that could affect the abundance and activity of NR bacteria. The abundance of heterotrophic bacterial groups in any environment is related directly to the ability to utilize the available organic carbon sources as an energy source. In hydrocarbon-contaminated soils, hydrocarbons can be a source of carbon for those bacteria that possess pathways for hydrocarbon degradation. Nitrate reducing bacteria are typically facultative anaerobes, and thus they may possess the aerobic pathways of hydrocarbon degradation such as that found in Pseudomonas putida pG7, which contains the NAH7 naphthalene-degradation plasmid (Dunn and Gunsalus, 1973). In addition, they may have an advantage over aerobes in being able also to degrade hydrocarbons under NR conditions if they possess a pathway active under NR conditions. Pseudomonas fluorescens B-3468 may be such an organism, as it converted 2,4,6-trinitrotoluene under conditions of oxygen or nitrate respiration (Naumova et al., 1988). Various studies investigated the anaerobic degradation of polyaromatic hydrocarbons (PAHs) under NR and DN conditions. One laboratory study (al-Bashir et al., 1990) showed biodegradation of low molecular weight PAHs when denitrifying organisms were grown. Also, nitratedependent anaerobic degradation and mineralization of naphthalene by pure cultures of Pseudomonas stutzeri and Vibrio pelagius has been demonstrated (Rockne et al., 2000). Therefore, we hypothesized that the abundance of hydrocarbon-degrading NR and DN bacteria will increase in the crude oil-contaminated sites. However, the range of organisms that degrade most low- molecular-weight components of mineral oil decreases with increasing salinity (Kleinsteuber et al., 2006). Therefore, soils contaminated with both brine and oil may be more difficult to be bioremediated, although it was shown that levels of TPH were reduced in the presence of brine contamination (Sublette et al., 2005). One more environmental factor that affects NR and DN bacteria in soils is the availability of nitrate. It has been shown that the addition of plant residues can lead to a long-term increase in potential nitrate reduction activity and size of a microbial community involved in nitrogen cycling. However, the effect of the type of plant residue itself was limited (Chèneby et al., 2010). Therefore, nitrogen-containing fertilizers are often used in bioremediation (Pope and Matthews, 1993).In fact, the fertilizers used in this study contained ammonium nitrate (NH4NO3) (Sublette et al., 2007a).

Considering the effect of these environmental factors one by one, and in combination, since the amount of water available in soil (soil moisture) plays such an important role in microbial activity and particularly for NR and $\mathrm{DN}$ bacteria by also affecting available oxygen levels, we hypothesize that bacteria numbers and the relative abundance of NR and DN bacteria increase with higher soil moisture. Also, since crude oil contamination alters bacterial communities in soils by providing alternative carbon sources and killing sensitive members of the microbial community (Sikkema et al., 1995) and many NR and DN are hydrocarbon degraders (Al-Bashir et al., 1990; Sharak Genthner et al., 1997; Rockne and Strand, 1998) we hypothesize that NR and DN bacteria will be more abundant in the crude oil-contaminated soils compared to that in the prairie uncontaminated soils, if the moisture levels are comparable. However, NR and DN bacteria will be less abundant in the sites that are contaminated with both oil and brine because salinity decreases the range of microorganisms that degrade most low-molecular-weight components of mineral oil (Kleinsteuber et al., 2006). Remediation treatments of nitrate fertilizer are expected to stimulate the activity and eventually increase the numbers of NR and DN bacteria. Therefore, we hypothesized the best conditions for NR and DN bacteria are soils contaminated with hydrocarbons, and remediated by application of nitrate containing fertilizer and watered. However, it is unknown whether the potentially stimulating effect on NR and DN bacteria of nitrate remediation of oil contaminated soils persists over a period of several years.

\section{Materials and Methods}

The sampling sites used in this work are located in the Tallgrass Prairie Preserve (TPP) in Osage County, Oklahoma. Nitrate reducing and denitrifying bacteria were isolated from a total of 5 contaminated sites designated as G5, G7, LF, J6-F, and J6-NF and 4 adjacent uncontaminated sites (G5P, J6P, G7P, and LFP). Leaks from oil pipelines had contaminated the sites with crude oil (J6-F, J6-NF, LF) or with a mixture of brine and oil (G5, G7). The sites had been partially remediated as described previously (Sublette et al., 2005; Sublette et al., 2007a; Duncan et al., 1998; Duncan et al., 1999). Briefly, the contaminated sites were contaminated during 1996-2000 but still contained 
Table 1. Values for TPH, Na+, Cl-, and NO3- near MPN sampling dates.

Table 1a. Total petroleum hydrocarbons (TPH).

\begin{tabular}{cccc}
\hline \multirow{2}{*}{ Site } & \multicolumn{3}{c}{ TPH $^{\mathbf{a}}$} \\
\cline { 2 - 4 } & Sampling Date & \# Samples & (mg/kg) $\left.\mathbf{( S D}^{\mathbf{b}}\right)$ \\
\hline J6-NF & April/June 2003* & 2 & $1957.5(958.13)$ \\
J6-F & April/June 2003* & 2 & $959(59.4)$ \\
J6P & April/June 2003* & 2 & $0(0)$ \\
G5 & April 2003** & 3 & $315(270)$ \\
G5P & April 2003 & 1 & $100(\mathrm{~N} / \mathrm{A})$ \\
G7 & Spring 2005 & 12 & $10941(1068)$ \\
LF & Spring 2005 & 34 & $14321(3163)$ \\
\hline
\end{tabular}

aTotal Petroleum Hydrocarbons. ${ }^{b}$ Standard deviation. *One sample was taken in April 2003, one in June 2003, and averaged. ${ }^{* *}$ One sample was taken from G5N, one from G5M, one from G5S, and averaged. N/A: Not applicable. Data from Sublette et al. 2005, 2007, and unpublished data.

Table 1b. Brine components and NO3-.

\begin{tabular}{|c|c|c|c|c|c|}
\hline Site & Sampling Date & \# Samples & $\mathrm{Na}^{+}(\mathrm{mg} / \mathrm{kg})(\mathrm{SD})$ & $\mathrm{Cl}^{-}(\mathrm{mg} / \mathrm{kg})(\mathrm{SD})$ & $\mathrm{NO}_{3}^{-}(\mathrm{mg} / \mathrm{kg})(\mathrm{SD})$ \\
\hline J6-NF & June 2003 & 4 & $\mathrm{BDL}$ & BDL & $4.18(3.22)$ \\
\hline J6-F & June 2003 & 5 & BDL & BDL & $12.74(6.73)$ \\
\hline J6P & June 2003 & 4 & BDL & BDL & $0.70(0.12)$ \\
\hline G5 & April/June 2003 & $3^{\mathrm{a}}$ or $26^{\mathrm{b}}$ & $896(402)^{\mathrm{a}}$ & $1478(859)^{\mathrm{a}}$ & $28.12(13.58)^{b}$ \\
\hline G5P & April/June 2003 & $1^{a}$ or $9^{b}$ & $29^{\mathrm{a}}(\mathrm{N} / \mathrm{A})$ & $0^{\mathrm{a}}(\mathrm{N} / \mathrm{A})$ & $0.82(0.17)^{b}$ \\
\hline G7 & July 2005 & 32 & $288(79.88)$ & $99.8(42.98)$ & $1.7(0.74)$ \\
\hline $\mathbf{L F}$ & August 2005 & 32 & $50(9.09)$ & BDL & $12.4(13.45)$ \\
\hline
\end{tabular}

a: $\mathrm{Na}^{+}, \mathrm{Cl}^{-}$samples $(\mathrm{N}=3$ for $\mathrm{G} 5, \mathrm{~N}=1$ for G5P), samples were taken in April 2003. For G5, one sample was taken from G5N, one from G5M, one from G5S, and averaged. b: $\mathrm{NO}_{3}{ }^{-}$samples ( $\mathrm{N}=26$ for $\mathrm{G} 5, \mathrm{~N}=9$ for G5P), samples were taken in June 2003. For G5, 9 samples were taken from G5N, 9 from G5M, 8 from G5S, and averaged. For G5P, 9 samples were averaged. BDL: below detected limits (e.g. the method detection limits were: $10 \mathrm{mg} / \mathrm{kg}$ for TPH, 1 $\mathrm{mg} / \mathrm{kg}$ for brine components. N/A: not ap plicable. Data from Sublette et al. 2005, 2007, and unpublished data.

low levels of TPH and $\mathrm{Na}^{+}$and $\mathrm{Cl}^{-}$(Tables 1.a and 1.b) when sampled for the current study. Sites G7 and LF underwent a further round of treatment immediately prior to the course of this research as described in the Materials and Methods. The objective of this study was to determine the association of different environmental factors (e.g. TPH, $\mathrm{NaCl}$, nitrate and soil moisture) with the abundance of NR and DN bacteria in long-term contaminated vs. uncontaminated prairie soils in order to determine which factors have an impact under field conditions.

The following is a brief summary of the timeline of contamination and remediation of each site. The reader may consult the referred sources for more details. The G5 site was contaminated in the fall of 1999 by 3 separate breaks in the same line resulting in 3 lobes of contamination (e.g. G5N, G5M, and G5S). The amount spilled was unknown, but the water to oil ratio in this line was 10-15:1, and the brine had a total dissolved solids (TDS) of $105,000 \mathrm{mg} / \mathrm{L}$. The initial TPH values were estimated as $1300-5200 \mathrm{mg} / \mathrm{kg}, \mathrm{Na}^{+}$as $1100-1580 \mathrm{mg} / \mathrm{kg}$, and $\mathrm{Cl}^{-}$as $780-$ $2450 \mathrm{mg} / \mathrm{kg}$ (Sublette et al., 2005). Remediation, as described in Sublette et al. (2005), was performed from June 2000 to August 2003 and consisted of hay and fertilizer containing nitrate, and installation of a drainage pipe downhill from the contaminated area. The J6 site was contaminated in January 1999 by a pipe break resulting in a spill of approximately $11 \mathrm{~m}^{3}$ of dewatered crude oil. The initial Total Petroleum Hydrocarbon (TPH) con- centration (EPA 418.1) was about 33,500 mg/kg (dry wt. basis) when remediation was initiated (following tilling) (Sublette et al., 2007a). Remediation, as described in Sublette et al. (2007a), was performed from May 1999 to October 2001 and consisted of hay, fertilizer containing ammonium nitrate $\left(\mathrm{NH}_{4} \mathrm{NO}_{3}\right)$, diphosphorus pentoxide $\left(\mathrm{P}_{2} \mathrm{O}_{5}\right)$, and potassium oxide $\left(\mathrm{K}_{2} \mathrm{O}\right)$, and tilling. J6 was divided into two sections, fertilizer was applied by tilling in four increments throughout the 2 year-period of remediation on J6-F, while J6-NF was tilled in parallel with J6-F but not fertilized. The G7 site was affected primarily by brine. The original spill was in 2000 , remediation treatments of hay and nitrate-containing fertilizer were performed, ending in 2004, and the sodium and chloride levels were reduced, but large expanses still had no plants in 2005. Sodium and chloride levels varied widely, with sodium ranging from $350-600 \mathrm{mg} /$ $\mathrm{kg}$ soil (Sublette et al., 2004). On the other hand, LF, containing soil contaminated by a spill of crude oil, was remediated in 1996 and 1997 by mixing the contaminated soil with the uncontaminated soil plus nitrogen-containing fertilizer (Duncan 1998, 1999). During that time, TPH levels decreased to about a third of the original level and plants grew over most of the site, but they were primarily weedy, non-native, undesirable species.

During the period of 2005-2006, treatments were performed on the G7 and LF sites in order to further decrease the contami- 
nation levels. The areas treated were approximately $45.72 \mathrm{~m} \mathrm{x}$ $15.24 \mathrm{~m} \mathrm{(G7)} \mathrm{and} 27.43 \mathrm{~m} \times 25.91 \mathrm{~m}(\mathrm{LF})$. Restoration treatments were started in the spring of 2005 by ripping the soil to a depth of $30 \mathrm{~cm}$ and tilling. Each site was divided into 4 blocks, and soil within each block was homogenized by mixing before being distributed into 36 enclosures per block. The homogenized soil was placed inside a bag of bridal veil material, inside a $30 \mathrm{~cm}$ diameter PVC pipe enclosure with slots drilled into it for drainage. Each $30 \mathrm{~cm}$ enclosure was centered in $2 \mathrm{~m} \times 2 \mathrm{~m}$ area within the block (QAPP: Quality Assurance Project Plan, 2004). The soil inside each enclosure received one of the 4 following treatments: hay alone, fertilizer alone, hay plus fertilizer, and the fourth treatment being no fertilizer and no hay. The fertilizer was mixed into the top $15 \mathrm{~cm}$ of soil, and the hay was placed on the soil surfaces. Each block contained 4 repetitions of each treatment, and one of each treatment per block was destructively sampled on each sampling. An additional enclosure from LF, G7, or both, was collected on most sampling dates for quality control purposes giving a total of 33-34 samples. Soil for an MPN series was obtained from each destructed sample. After adding the amendments, the entire site was covered with hay. The enclosures were installed and the amendments added in May 2005 and watering began (Sublette et al., 2004).

All samples were obtained from the Tallgrass Prairie Preserve in Osage County, Oklahoma. Soil samples were collected from the following sites: G5 (brine/oil contaminated) (Sublette et al., 2005), J6-F (crude oil contaminated, treated with fertilizer) (Sublette et al., 2007a), and J6-NF (crude oil contaminated, not treated with fertilizers) (Sublette et al., 2007a) in March, 2005. In addition, soil samples were obtained from G7 (brine/ oil contaminated) in July 2005, October 2005, and June 2006, and from LF (crude oil contaminated) in August 2005, October 2005, and June 2006. Samples from adjacent uncontaminated sites (G5P, J6P, G7P, and LFP) were collected at the same time as for contaminated sites. Briefly, for G5 and J6 sites, a trowel was used to remove 5 scoops of soil from 5 widely spaced points within a $25 \mathrm{~m}$ radius from approximately the top $10 \mathrm{~cm}$ of soil, beginning just below any loose litter layer, and placed in Whirl-pac ${ }^{\circledR}$ bags. Then, these soil samples from G5, J6-F, J6$\mathrm{NF}$ and their parallel uncontaminated sites were homogenized in autoclaved beakers using autoclaved spoons. The enclosures in LF and G7 were pulled out and the soil poured into stainless steel bowls, mixed and subsamples were taken out for a variety of assays. Approximately $300 \mathrm{~g}$ of homogenized soil from each of 33 or 34 enclosures was subsampled from LF and G7 sites for MPN assays (see Materials and Methods for more detailed information).

Nitrate broth medium for detection of NR and DN bacteria consisted of $2.5 \mathrm{~g}$ of $\mathrm{NaNO}_{3}$ added to $500 \mathrm{~mL}$ of nutrient broth (Difco Inc., Detroit, MI) before autoclaving. The antifungal agent, cycloheximide (Sigma Chemical Company, St. Louis, MO) $(100 \mu \mathrm{g} / \mathrm{mL}$ final plate concentration) was added after autoclaving. Nitrate Reduction Broths containing beef extract, pancreatic digest of casein, or peptone, are commonly used to distinguish facultative heterotrophic bacteria based on whether they are able to reduce nitrate to nitrite or produce $\mathrm{N}_{2}$ gas (Atlas, 1993). Control strains were used to confirm that the test condi- tions (e.g. detection of NR and DN bacteria in the presence of soil) correctly identified nitrate reducers and denitrifyers. These controls were: Pseudomonas aeruginosa ATCC 27853 (denitifyer), P. putida F1 ATCC 17485 (negative- neither a denitrifyer nor a nitrate reducer). P. aeruginosa S1-1 (a denitrifying bacterium isolated from tallgrass prairie), and P. putida $\mathrm{pG} 7$ (neither a denitrifyer nor a nitrate reducer). P. aeruginosa strains were grown at $37^{\circ} \mathrm{C}$ and $P$. putida strains were grown at room temperature $\left(23-25^{\circ} \mathrm{C}\right)$.

Soils were initially mixed in Whirl-pac ${ }^{\circledR}$ bags using autoclaved spoons in the field and later in the lab were further homogenized in autoclaved beakers by mixing with autoclaved spoons. After homogenization, $2.00 \mathrm{~g}$ soil (wet weight) from each sample was added to a sterile $50 \mathrm{ml}$ centrifuge tube containing $18 \mathrm{~mL}$ of sterile isotonic saline $(0.85 \% \mathrm{NaCl})$, vortexed for 1 minute and serially diluted $(1: 10)$ to $10^{-8}$ for all samples. Twenty microliters of each dilution was used to inoculate 180 $\mu 1$ of the nitrate broth (see A. Medium) in 5-fold replicate, making a five tube MPN series (Rodina, 1972). The inoculated microtiter plates were incubated at room temperature $\left(23-25^{\circ} \mathrm{C}\right)$ in the dark for 14 days (Jones et al., 1991). All wells were examined for evidence of growth (turbidity) after 14 days, and those that were turbid were scored positive for aerobic/facultative heterotrophic bacteria. Subsequently, half of the volume of the wells was transferred to a fresh microtiter plate and tested for the presence of NR and DN bacteria using Griess reagents (Baron and Finegold, 1990; Smibert and Krieg, 1994). Briefly, 2 drops of reagent 1 (Sulfanilic acid) and 2 drops of reagent $2(\mathrm{~N}$, N-Dimethyl-1- naphthylamine) (bioMérieux Vitek, Inc., Hazelwood, MO) were added to every well. The presence of nitrite is detected by a red color after the addition of reagents 1 and 2, e.g, indicating nitrate reduction. If the medium remained colorless, e.g. no nitrite formed, it is due either to lack of reduction of nitrate, e.g. no nitrate reduction or the reduction of nitrite to other products, such as $\mathrm{NO}, \mathrm{N}_{2} \mathrm{O}$, or $\mathrm{N}_{2}$, hence denitrification. If the medium remained colorless, zinc metal dust (Mallinckrodt Chemical Works, St. Louis, MO) was used to detect if unreduced nitrate was present by reducing nitrate to nitrite and turning the medium pink or red. Therefore, pink or red after zinc dust indicates neither NR nor DN bacteria. If colorless after zinc dust, the well was assumed to contain DN bacteria. However, since only the loss of nitrate and nitrite was demonstrated, bacteria in the colorless wells could be nitrite reducers rather than performing the entire denitrification pathway. Calculation of \# of viable cells from MPN reading used the 5-tube MPN tables (Rodina, 1972), and were corrected for the \% soil moisture to give estimated \# cells/g soil (dry weight).

To test whether the presence of soil interferes with the ability to detect the reduction of nitrate/nitrite in the microtiter plate test format, the four Pseudomonas control strains of known phenotype previously described (see Materials and Methods) were tested. Tests with $P$. aeruginosa strains were performed at $37^{\circ} \mathrm{C}$, those with $P$. putida at room temperature $\left(23-25^{\circ} \mathrm{C}\right)$. A small colony from each Pseudomonas strain was resuspended in $1.0 \mathrm{~mL}$ of sterile isotonic saline $(0.85 \% \mathrm{NaCl})$ and vortexed. The inoculated saline was added to $1 \mathrm{~g}$ of autoclaved soil that came from G5P site. The inoculated saline and soil were added 
to $8 \mathrm{~mL}$ of sterile saline to produce a 1:10 dilution (e.g. 10-1). An additional 1:10 dilution was performed and $20 \mu \mathrm{l}$ diluted cell suspension added to wells of a microtiter plate containing $180 \mu 1$ of nitrate broth. The inoculated microtiter plates were incubated at room temperature $\left(23-25^{\circ} \mathrm{C}\right)$ in the dark for 14 days (Jones et al., 1991) and scored for growth and for the reduction of nitrate or nitrite as described previously.

Soil moisture for all samples was determined from the original soil mass by gravimetric measurements of two $10 \mathrm{~g}$ samples (wet weight) after oven drying (Wollum, 1982). The $\%$ soil moisture was calculated as $\%$ soil moisture $=(\mathrm{g}$ water $\mathrm{g}$ wet soil) $x$ 100. Samples were taken from both the contaminated and the prairie sites. G7 and LF were regularly irrigated throughout the study. The other sites received only natural rainfall. Soil moisture for G5, J6-F, J6-NF, G5P, and J6P was measured for March 2005. Soil moisture for G7 and G7P was measured for July 2005, October 2005, and June 2006 at the time of sampling. Soil moisture for LF and LFP was measured for August 2005, October 2005, and June 2006 at the time of sampling. Brine components $\left(\mathrm{Na}^{+}, \mathrm{Cl}^{-}\right)$were extracted from oven-dried soil with deionized water, and concentrations were determined by ion chromatography (Harris, 1998). Continental Laboratories (Salina, KS, USA) performed TPH analysis of soil samples by using Environmental Protection Agency (EPA) method 418.1. Nitrate was measured in Oklahoma State University Laboratory (Stillwater, OK, USA). Metadata was collected from different studies that include $\mathrm{TPH}, \mathrm{Na}^{+}, \mathrm{Cl}^{-}$, and $\mathrm{NO}_{3}$ in contaminated-treated (G5, G7, LF, J6-F, and J6-NF) and prairie (G5P, G7P, LFP, and J6P) sites (Duncan et al., 1999; Sublette et al., 2005; Sublette et al., 2007a).

Mean, standard deviation, coefficient of variation, and linear regression were calculated using Microsoft Excel version 2007. Also, one-way ANOVA, 2-way ANOVA, and Duncan's multiple range tests were used to analyze the data using Statistical Package for the Social Sciences (SPSS for Windows version 19.0, IBM, Chicago, Ill, USA). In addition, Student's T test and Welch's test were used to compare data using GraphPad Prism Ver. 3 (GraphPad Software, San Diego, CA, USA). The data were considered significantly different if the two-tailed P-value was $<0.05$. MPN values were converted to $\log _{10}$ values for statistical analysis in order to normalize the data for parametric statistical tests.

\section{Results}

\section{Contaminant Levels at the Beginning of the Study}

Metadata was collected from different published studies and summarized in Table 1 to show the levels of $\mathrm{TPH}, \mathrm{Na}^{+}, \mathrm{Cl}^{-}$, and $\mathrm{NO}_{3}^{-}$for sampling dates closest to those representing the beginning of the current study. Samples for the metadata were taken prior to site manipulation for G7 and LF. The metadata we collected show that there was a significant difference $(\mathrm{P}<0.05)$ between TPH in G7 (primarily brine-contaminated) and that in LF (crude oil contaminated) when sampled in spring 2005 with G7 being lower (Table 1.a). (Welch's approximate $\mathrm{t}=5.417,43$ d.f., mean difference $=3380.0,95 \% \mathrm{CI}=2121.7-4638.3)$. On the other hand, there was no significant difference $(\mathrm{P}>0.05)$ between TPH in J6-NF and that in J6-F during the period of April/June 2003. (Welch's approximate $t=1.471,1$ d.f., mean difference $=-998.50,95 \% \mathrm{CI}=-9623.3-7626.3$ ).

Nitrate-containing fertilizer was applied once in May 2005 to selected enclosures in the G7 and LF sites. Nitrate-containing fertilizer was last applied in June 2000 to J6-F and samples taken in June 2003. Fertilizer was applied in April 2001 to G5 and samples taken in April/June 2003. Nitrate levels varied in different sites (Table 1.b). When we compared nitrate levels in J6-NF, J6-F, and J6P, there was a significant difference ( $\mathrm{P}<$ $0.05)$ in nitrate concentration among those 3 sites. Nitrate level in J6-F was higher than that in J6-NF or J6P $(\mathrm{P}<0.05)$, with no significant difference between J6-NF and J6P (Tukey-Kramer Multiple Comparisons Test. Mean difference (J6-NF vs J6-F), = $-8.560,95 \% \mathrm{CI}=-17.034$ to -0.08612 ; Mean difference (J6-NF vs J6P) $=3.480,95 \% \mathrm{CI}=-5.452-12.412$; and Mean difference $(\mathrm{J} 6-\mathrm{F}$ vs J6P) $=12.040,95 \% \mathrm{CI}=3.566$ to 20.514$)$. Finally, nitrate levels were significantly higher $(\mathrm{P}<0.05)$ in G5 (e.g. G5N, G5M, and G5S) than that in G5P (Welch's approximate $t$ $=10.248,25$ d.f., mean difference $=-27.300,95 \% \mathrm{CI}=-32.786$ $--21.814)$.

\section{MPN Assays}

Table 2 summarizes MPNs for each site and each sample date, $\% \mathrm{NR}$ and DN bacteria (e.g. "\#NR and DN/ \#heterotrophs" $\mathrm{x}$ 100 ), and soil moisture percentages. Although the MPN assays correctly indicated Pseudomonas control strains as denitrifyers in the absence of soil, when autoclaved soil was added to the dilution series, control DN strains were scored as nitrate reducers (NR), e.g. nitrate was consumed but not nitrite. Therefore, NR bacteria were not reliably distinguished from DN bacteria when scoring MPNs from the soil, and wells showing loss of nitrate and/or nitrite were reported as NR and DN bacteria.

\section{The Association of Soil Moisture Levels with NR and DN Bacteria: J6 and G5 Sites}

The J6-NF, J6-F, J6P, G5 (includes the N, M, and S lobes), and G5P sites were analyzed together as they represent contaminated and parallel uncontaminated sites (eg. J6P, G5P) that were not treated during the period of study and were sampled on the same dates. Table 2 shows the $\%$ soil moisture [ $=$ ( $\mathrm{g}$ water $/ \mathrm{g}$ wet soil) $x$ 100] in the J6 and G5 soils sampled in March 2005 (Figure 1, One-way ANOVA: F $(4,9)=89.988, p=0.000$ ). The uncontaminated prairie samples bounded the range of $\%$ soil moisture, with G5P being the lowest (13.6\%) and J6P the highest (21\%). Post Hoc tests (e.g. Duncan's multiple range test) group together the homogenous subsets showing that soil moisture in G5P was significantly lower than \% soil moisture in the others, J6-NF next lowest, G5 and J6-F grouped together, and J6P with the highest \% soil moisture (Figure 1).

Estimated viable counts of either heterotroph or NR/DN bacteria varied little with the \% soil moisture (Table 2, Figure 1), with the exception of J6-F. It was estimated there were $1.07 \mathrm{x}$ 107 culturable heterotrophic bacteria/g soil in G5P (13.6\% soil 
Table 2. Most Probable Numbers (MPNs) of NR and DN bacteria, heterotrophic bacteria, \%NR and DN bacteria, and \% soil moisture.

\begin{tabular}{lllcccc}
\hline Site & Date & $\mathbf{N}$ & $\begin{array}{c}\text { \% Soil Moisture } \\
\text { (SD) }\end{array}$ & $\begin{array}{c}\text { NR and DN bacteria } \\
(\text { SD) }\end{array}$ & $\begin{array}{c}\text { Heterotrophs } \\
\text { Mean (SD) }\end{array}$ & $\begin{array}{c}\text { \% NR and DN } \\
\text { Bacteria (SD) }\end{array}$ \\
\hline G5P & Mar-05 & 1 & $13.6(0.14)^{* *}$ & $2.80 \times 10^{6}(\mathrm{~N} / \mathrm{A})$ & $1.07 \times 10^{7}(\mathrm{~N} / \mathrm{A})$ & $26.17(\mathrm{~N} / \mathrm{A})$ \\
J6-NF & Mar-05 & 1 & $16.55(0.07)^{* *}$ & $5.60 \times 10^{6}(\mathrm{~N} / \mathrm{A})$ & $1.44 \times 10^{7}(\mathrm{~N} / \mathrm{A})$ & $38.89(\mathrm{~N} / \mathrm{A})$ \\
J6-F & Mar-05 & 1 & $17.45(0.35)^{* *}$ & $3.40 \times 10^{7}(\mathrm{~N} / \mathrm{A})$ & $4.72 \times 10^{7}(\mathrm{~N} / \mathrm{A})$ & $72.03(\mathrm{~N} / \mathrm{A})$ \\
G5 & Mar-05 & 3 & $18.02(0.51)^{* *}$ & $5.10 \times 10^{6}\left(5.2 \times 10^{5}\right)$ & $1.50 \times 10^{7}\left(3.49 \times 10^{6}\right)$ & $35.08(7.90)$ \\
J6P & Mar-05 & 1 & $21(0.14)^{* *}$ & $5.00 \times 10^{6}(\mathrm{~N} / \mathrm{A})$ & $1.78 \times 10^{7}(\mathrm{~N} / \mathrm{A})$ & $28.09(\mathrm{~N} / \mathrm{A})$ \\
G7P & Oct-05 & 2 & $12.85(0.21)$ & $2.02 \times 10^{6}\left(7.78 \times 10^{4}\right)$ & $1.96 \times 10^{7}(0)$ & $10.28(0.40)$ \\
G7P & Jun-06 & 4 & $13.7(1.49)$ & $1.54 \times 10^{6}\left(9.79 \times 10^{5}\right)$ & $6.94 \times 10^{6}\left(2.61 \times 10^{6}\right)$ & $26.90(19.89)$ \\
G7 & Jul-05 & 34 & $25.8(2.78)$ & $5.76 \times 10^{6}\left(6.04 \times 10^{6}\right)$ & $1.96 \times 10^{7}\left(2.68 \times 10^{7}\right)$ & $51.92(39.92)$ \\
G7 & Oct-05 & 34 & $23.3(2.78)$ & $7.29 \times 10^{6}\left(9.10 \times 10^{6}\right)$ & $3.66 \times 10^{7}\left(2.87 \times 10^{7}\right)$ & $22.40(24.67)$ \\
G7 & Jun-06 & 34 & $22.8(2.17)$ & $2.14 \times 10^{7}\left(2.39 \times 10^{7}\right)$ & $4.02 \times 10^{7}\left(2.42 \times 10^{7}\right)$ & $55.2(27.40)$ \\
LFP & Oct-05 & 2 & $12.95(0.07)$ & $1.66 \times 10^{6}\left(1.06 \times 10^{6}\right)$ & $1.40 \times 10^{7}\left(1.44 \times 10^{7}\right)$ & $16.96(9.84)$ \\
LFP & Jun-06 & 4 & $13.50(1.74)$ & $2.60 \times 10^{6}\left(2.09 \times 10^{6}\right)$ & $3.52 \times 10^{6}\left(1.56 \times 10^{6}\right)$ & $69.95(35.11)$ \\
LF & Aug-05 & 34 & $20.7(4.51)$ & $4.92 \times 10^{6}\left(7.07 \times 10^{6}\right)$ & $7.06 \times 10^{7}\left(2.51 \times 10^{8}\right)$ & $31.52(33.65)$ \\
LF & Oct-05 & 34 & $18.9(4.17)$ & $1.06 \times 10^{7}\left(1.26 \times 10^{7}\right)$ & $6.12 \times 10^{9}\left(3.23 \times 10^{10}\right)$ & $24.44(29.52)$ \\
LF & Jun-06 & 34 & $18.9(5.31)$ & $1.46 \times 10^{7}\left(1.70 \times 10^{7}\right)$ & $2.77 \times 10^{7}\left(2.71 \times 10^{7}\right)$ & $55.50(30.29)$ \\
\hline
\end{tabular}

Date: Soil sampled collected for MPN estimation. N: Number of samples. N/A: Not applicable. *Average per gram dry weight soil estimated from 5-tube MPN (Rodina, 1972). ${ }^{* *}$ Moisture \%: The average of 6 samples for G5, and an average of 2 for each J6-NF, J6-F, G5P, and J6P from soil wet weight for G7 and LF, N=the value listed. \% Soil moisture $=(\mathrm{g}$ water/g wet soil) $\mathrm{x}$ 100. Soil moisture was calculated from 2 soil samples per sample. SD: Standard deviation. NR and DN: Nitrate reducing and denitrify ing bacteria.

moisture) and $1.78 \times 107$ culturable heterotrophic bacteria/g soil in J6P (21\% soil moisture) but $4.72 \times 107 / \mathrm{g}$ soil in J6-F (17.5\% soil moisture). Estimates of DN/NR bacteria were about one quarter to one third that of the heterotrophic bacteria (Table 2), again with the exception of J6-F, in which estimates of DN/NR bacteria were about $70 \%$ that of the heterotrophic bacteria. .

\section{Soil Moisture Association with NR and DN Bacteria: G7 and LF Sites}

Figure 2 plots average and standard deviation of \% soil moisture values in G7 and LF sampled at different seasons during the experiment. Bars with the same numbers form homogeneous sets (Duncan's multiple range test). Our moisture results showed that highest \% soil moisture values were obtained in July 2005 (G7, Fig. 2a) and in August 2005 (LF, Fig. 2b). Note that the uncontaminated samples (G7P, LFP) were drier than the samples from the contaminated sites collected at the same time since the contaminated sites were watered throughout the study. Figures 2.a and 2.b also show that in spite of attempts to control water content, G7 generally was wetter than LF. Multiple samples were obtained from each site for every sampling date, which allowed us to more closely investigate the association between MPN values and soil moisture. Repeatedly, for each site and sampling date, our moisture versus MPN results in G7 and LF sites showed that the slope of the regression line was very nearly zero indicating similar MPN values over a fairly broad range of moisture levels (Figures $3 a$ and $3 b$, Table 2). In addition, the abundance of heterotrophic and DN/NR bacteria did not show a consistent pattern of association - the bivariate correlation between the number of heterotrophic and DN/NR in a particular sample ranged from -0.49 to +0.79 (Table 3 ).

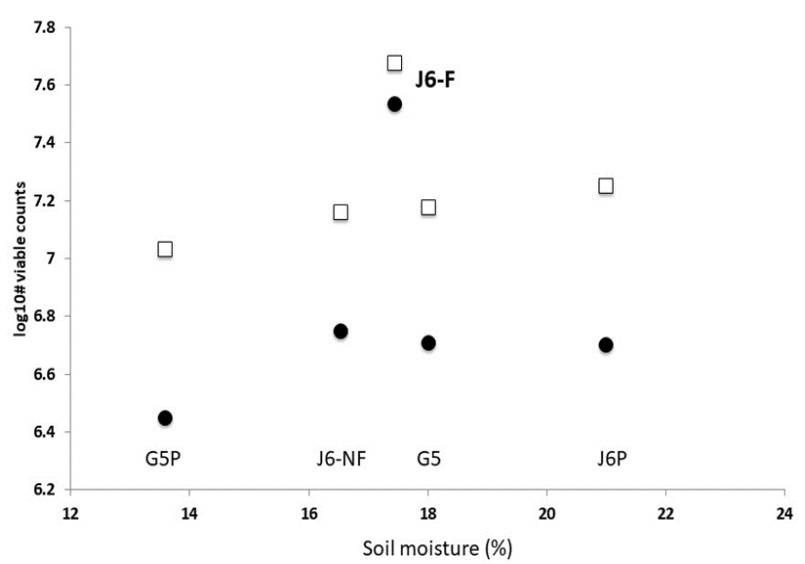

Figure 1. Abundance of heterotrophic and NR/DN bacteria with respect to soil moisture (sites G5, J6). The $\log 10$ \# viable counts (MPN) for heterotrophic (open squares) and NR/DN (black circles) are plotted on the $\mathrm{Y}$ axis versus the $\%$ soil moisture (\% water/g soil wet wt) for samples taken from the G5 and J6 sites March 2005. See Tables 1 and 2 for additional information about the sites. $\mathrm{N}=1$ for MPN values and $\mathrm{N}=2$ (averaged) for each soil moisture value.

\section{Comparing MPN for G7 and LF Across all Sample Dates}

G7 MPN values (Table 2) for heterotrophic bacteria, NR and DN bacteria, and \%NR and DN bacteria for all sample dates of G7 and G7P were analyzed together. The abundance of heterotrophic bacteria with respect to G7 and G7P soils sampled on different dates varied significantly (One-way ANOVA: F $(4,103)=11.292, p=0.000)$. Duncan's multiple range test, a post-hoc test which groups together homogeneous subsets of 
Table 3. Bivariate correlation between $\log 10 \#$ heterotrophic and DN and NR bacteria.

\begin{tabular}{lc}
\hline Site / Date & Correlation \\
\hline G7/July2005 & 0.17 \\
G7/October 2005 & 0.05 \\
G7/June 2006 & 0.63 \\
G7P/June 2006 & -0.46 \\
LF/August 2005 & 0.22 \\
LF/October 2005 & -0.49 \\
LF/June 2006 & 0.79 \\
LFP/June 2006 & 0.74 \\
\hline
\end{tabular}

Table 4. \% Coefficient of variation (CV) of NR and DN and heterotrophic bacteria in G7, G7P, LF, and LFP sites.

\begin{tabular}{cccccc}
\hline Site & $\begin{array}{c}\text { Sample } \\
\text { Date }\end{array}$ & $\begin{array}{c}\text { Mean (SD) } \log _{10} \\
\text { NR and DN }\end{array}$ & $\begin{array}{c}\% \text { CV } \log _{10} \\
\text { NR and DN }\end{array}$ & $\begin{array}{c}\text { Mean (SD) } \\
\log _{\mathbf{1 0}} \text { Heterotrophs }\end{array}$ & $\begin{array}{c}\% \text { CV } \log _{\mathbf{1 0}} \\
\text { Heterotrophs }\end{array}$ \\
\hline G7 & Jul-05 & $6.43(0.82)$ & 13 & $7.06(0.43)$ & 6 \\
LF & Aug-05 & $6.40(0.57)$ & 9 & $7.23(0.56)$ & 8 \\
G7 & Oct-05 & $6.51(0.66)$ & 10 & $7.47(0.29)$ & 4 \\
G7P & Oct-05 & $6.30(0.02)$ & 0 & $7.29(0.00)$ & 0 \\
LF & Oct-05 & $6.72(0.59)$ & 9 & $8.03(0.91)$ & 11 \\
LFP & Oct-05 & $6.17(0.30)$ & 5 & $6.98(0.57)$ & 8 \\
G7 & Jun-06 & $7.2(0.31)$ & 4 & $7.5(0.32)$ & 4 \\
G7P & Jun-06 & $6.1(0.40)$ & 7 & $6.8(0.18)$ & 3 \\
LF & Jun-06 & $7.0(0.43)$ & 6 & $7.3(0.37)$ & 5 \\
LFP & Jun-06 & $6.3(0.35)$ & 6 & $6.5(0.19)$ & 3 \\
\hline
\end{tabular}

SD: standard deviation. \% CV: \% coefficient of variation $=(\mathrm{SD} / \mathrm{M}$ ean $) \times 100 \%$.

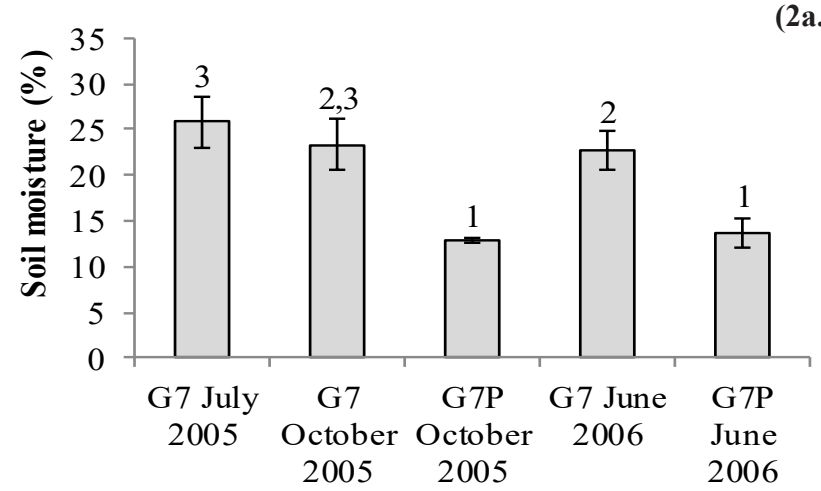

(2b.)

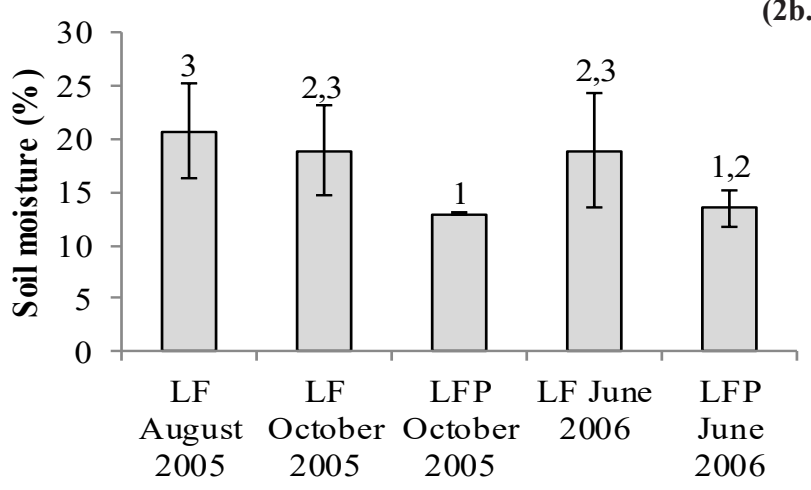

Figure 2. Moisture \% in G7 and LF sites. G7 July 2005, G7 October 2005, G7 June 2006, LF August 2005, LF October 2005, and LF June 2006: N=34. G7P June 2006 and LFP June 2006:N=4. G7P October 2005 and LFP October 2005:N=2. Bars indicate average values. Error bars indicate \pm 1 standard deviation. (2.a.) 1, 2, 3: Homogenous subsets (Duncan's multiple range test). One-way ANOVA: F $(4,103)$ $=31.341, \mathrm{p}=0.000$. (2.b.) 1, 2, 3: Homogenous subsets (Duncan's multiple range test). One-way ANOVA: $F(4,103)=3.420, p=0.011$. the data, grouped together G7P (June 2006) and G7 (July 2005) as having the lowest abundance of heterotrophic bacteria, G7 (July 2005), G7P (October 2005), and G7 (October 2005) as the group with the next to the lowest abundance, and G7P (October 2005), G7 (October 2005), and G7 (June 2006) as the subset with the highest abundance of heterotrophic bacteria. The $\log _{10}$ \#NR and DN bacteria varied significantly among the sites, with G7 (July 2005), G7P (October 2005, June 2006) lower than that in the remaining samples. One-way ANOVA (NR and DN: G7, G7P): $F(4,103)=9.142, p=0.000$. The $\% \mathrm{NR}$ and $\mathrm{DN}$ bacteria varied greatly among samples taken from the same site, with the least variation and lowest value in G7P (October 2005, Oneway ANOVA (\%NR and DN: G7, G7P): F $(4,103)=6.588$, p = 0.000 . For LF samples, the $\log _{10}$ \#heterotrophic bacteria value in LF October 2005 was significantly higher than that in the remaining samples (One-way ANOVA (Heterotrophs: LF, LFP): $F(4,102)=10.923, p=0.000)$. However, the $\log _{10} \# N R$ and DN bacteria value in LFP October 2005 is significantly lower than the remaining samples. One-way ANOVA (NR and DN: LF, LFP): $\mathrm{F}(4,102)=5.639, p=0.000$. Finally, the $\% \mathrm{NR}$ and DN bacteria varied greatly among samples taken from the same site, with the least variation and lowest value in LFP October 2005. One-way ANOVA (\%NR and DN: LF, LFP): $\mathrm{F}(4,102)=$ $5.915, p=0.000$.

\section{Coefficient of Variation (CV)}

The $\%$ coefficient of variation (CV) was calculated (Table 4 ) for the G7 and LF sites in order to estimate whether subsamples within a sample were more variable for numbers of DN/NR bacteria than for heterotrophs. Values of the CV for $\log _{10} \# \mathrm{NR}$ 
Table 5. Two-way ANOVA: Summary of significant treatment effects.

\begin{tabular}{cccccc}
\hline Site & Sample Date & Treatment & Dependent Variable & F value & Sig. \\
\hline G7 & Oct-05 & Hay & $\log _{10}$ NR and DN & 3.592 & 0.068 \\
G7 & Oct-05 & Hay & $\%$ NR and DN & 3.916 & 0.057 \\
G7 & Jun-06 & $\begin{array}{c}\text { Hay x Fertilizer } \\
\text { interaction }\end{array}$ & $\%$ NR and DN & 4.725 & 0.038 \\
& & Hay & $\log _{10}$ NR and DN & 3.721 & 0.063 \\
LF & Oct-05 & Hay & $\%$ NR and DN & 2.924 & 0.098 \\
LF & Oct-05 & Fertilizer & \%NR and DN & 4.436 & 0.044 \\
LF & Oct-05 & Fertilizer & \%NR and DN & 4.453 & 0.043 \\
LF & Jun-06 &
\end{tabular}

Significant treatment effects are defined as $\mathrm{p}<0.050$.
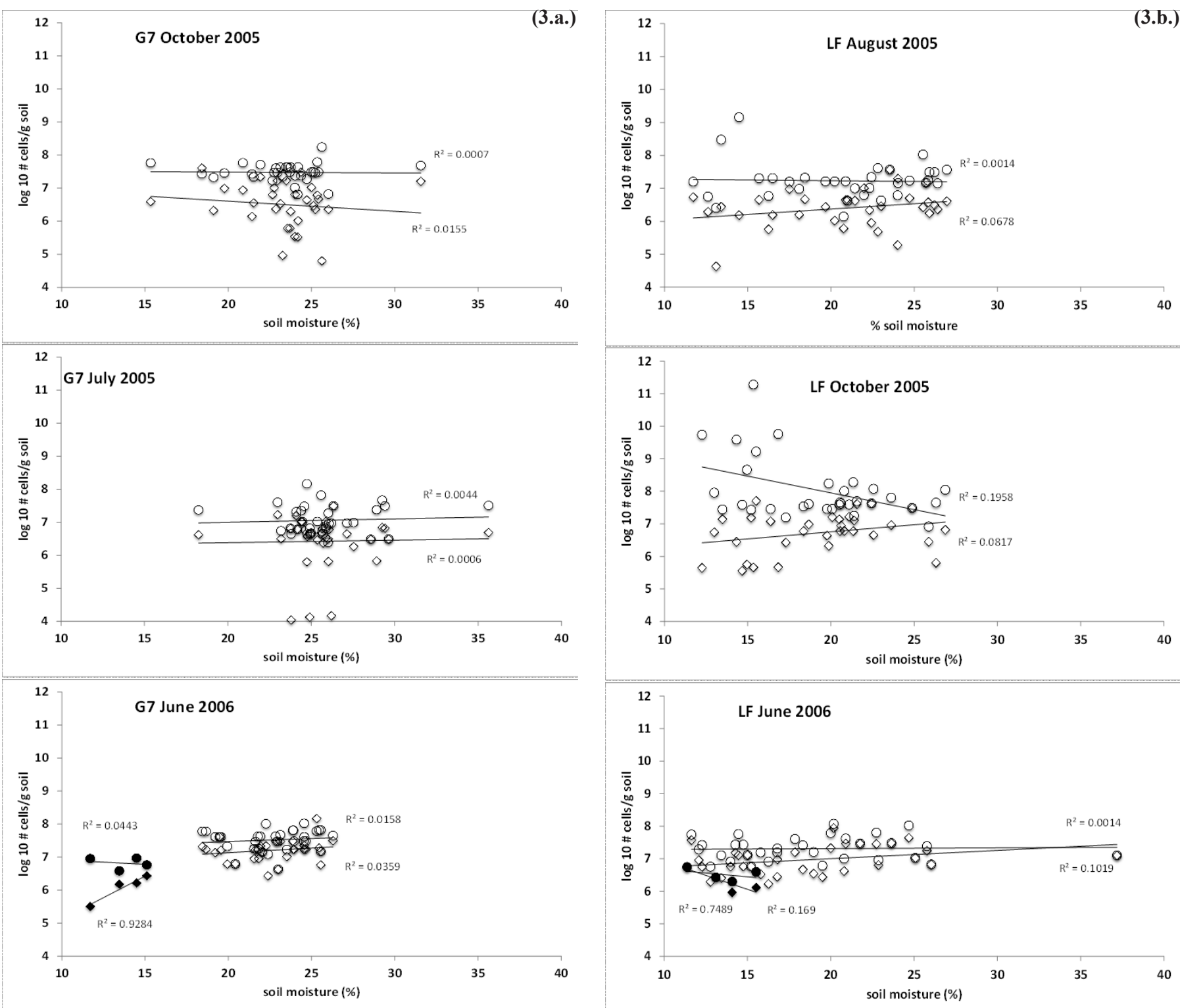

Figure 3. The relation between soil moisture and the $\log 10$ number of heterotrophic bacteria or $\log 10$ number of NR and DN bacteria in G7 or LF on different dates. Circles: heterotrophic bacteria. Diamonds: NR and DN bacteria. Open shapes: soils from contaminated sites ( $\mathrm{N}=33$ or 34). Filled shapes: soils from uncontaminated prairie sites ( $\mathrm{N}=2$ or 4$)$. $\mathrm{R} 2$ values for linear trend lines fitted to the data are shown on the figures. (3.a.) G7 samples; (3.b.) LF samples. 
and DN bacteria and for $\log _{10} \#$ heterotrophic bacteria ranged from $0-13 \%$. The CV was higher for $\log _{10} \#$ NR and DN bacteria than that for the $\log _{10} \#$ heterotrophic bacteria for 2 sample dates for G7, the same for June 2006, higher for 2 sample dates for LF and lower for LF October 2005. This indicates that there was proportionally more variation in abundance of NR and DN in LF and G7 than for heterotrophic bacteria sampled at the same time. Not as many samples were obtained from the uncontaminated sites, but in 2 out of 4 samples, the $\mathrm{CV}$ was higher for $\log _{10} \# \mathrm{NR}$ and DN than that for $\log _{10}$ \# heterotrophic bacteria, the same for one sample and lower for one sample (LFP October 2005).

\section{Two-way ANOVA: Effect of Hay and/or Fertilizer on Bacte- rial Numbers in $G 7$ and $L F$}

Hay and/or fertilizer were applied May 2005 to the soil in selected enclosures in the G7 and LF sites (Materials and Methods, "Restoration Phase"). Two-way ANOVA calculations were made to determine if there was a significant effect of applying hay and nitrate-containing fertilizer amendments on the abundance or proportion of NR and DN bacteria. Our multivariate analyses (e.g. 2-Way ANOVA) showed the effect $(p=0.038)$ of hay and fertilizer together on the relative abundance of NR and DN (\%NR and DN) bacteria sampled from G7 in June 2006 (Table 5). Enclosures where no hay and no fertilizer were applied had the highest \%NR and DN (69.5\%), followed by plus hay plus fertilizer (56.7\%), then plus hay no fertilizer (49.1\%), and the lowest was the no hay plus fertilizer treatment (38.3\%) (data not shown). Enclosures with fertilizer addition had higher $\% \mathrm{NR}$ and DN bacteria sampled from LF site in October 2005 $(p=0.044)($ Table 5$)$ where $\% \mathrm{NR}$ and DN was $13.9 \%$ with no fertilizer added and was $34.0 \%$ in enclosures when the fertilizer was added (data not shown). The opposite was true for June 2006, the greatest relative abundance of NR and DN bacteria sampled from LF site was $66.3 \%$ from enclosures with no fertilizer added and was $45.1 \%$ in enclosures when fertilizer was added in May 2005 ( $\mathrm{p}=0.043$ ) (Table 5) (data not shown). There was no significant effect on the hay and fertilizer treatments on the number or relative abundance of NR and DN bacteria for the remaining sample dates nor on the abundance of heterotrophic bacteria for any sample date.

\section{Discussion}

This study investigated the effect of the long-term (5-10 years) residual TPH and brine contamination on the abundance of NR and DN bacteria. Our results suggested that the residual TPH and brine levels were not associated with differences in abundance of NR and DN bacteria beyond that predicted by soil moisture levels in most cases. Our J6 study sites (TPH contaminated) sampled at an earlier stage after contamination showed that nitrogen mineralization rates in a contaminated non-fertilized soil (J6-NF) were significantly lower than that in a contaminated fertilized soil (J6-F, Sublette et al., 2007b). These low rates of nitrogen mineralization (e.g. tendency toward net immobilization) reflect reduced availability of inorganic nitrogen to NR and DN bacteria but MPNs were not performed. Nitrogen mineralization was not measured in the current study, but our MPN results show that there were no fewer NR and DN bacteria in the contaminated sites compared to those in the uncontaminated sites 5-10 years post contamination. Indeed, there was a higher $\%$ and greater number of NR and DN bacteria in J6-F than in J6NF or G5 sites (Table 2, Figure 1). Although MPN values for heterotrophs and $\mathrm{NR}$ and $\mathrm{DN}$ bacteria from the $\mathrm{LF}$ and G7 sites were similar over a broad range of moisture levels, the relative abundance of NR and $\mathrm{DN}$ bacteria had a wide range (e.g. $0 \%$ to $100 \%$ ) in different samples with the same moisture level, which suggests that factors other than current levels of soil moisture controlled the \% NR and DN bacteria. However, previous studies (Martin et al., 1988; Murray et al., 1995, Harms et al., 2009) showed that denitrifying bacteria are not uniformly distributed in soils and that samples from bulked soils are not representative of the actual distribution. In fact, denitrifying populations from selected sites can be much greater than those from other sites. Note that, as explained in the Materials and Methods, our soil samples from G7 and LF sites were homogenized within each block and placed in the enclosures, and further mixing was performed before sampling from enclosures. This multi-step homogenization might be expected to lower the heterogeneity in the distribution of denitrifying bacteria. However, the heterogeneity in $\log _{10}$ abundance of NR and DN bacteria and heterotrophic bacteria were shown by estimates of the coefficient of variation to be greater for G7 and LF samples (\% $\mathrm{CV}$ average for $\log _{10}$ of $\mathrm{NR}$ and $\mathrm{DN}=8.5 \%$, for $\log _{10}$ of heterotrophic bacteria $=6.3 \%, \mathrm{~N}=6$ ) than for the 4 samples taken from the uncontaminated sites (\% CV average for $\log _{10}$ of NR and $\mathrm{DN}=4.25 \%$, for $\log _{10}$ of heterotrophic bacteria $=3.5 \%$, N =4). Even after soil homogenization, CV was still greater for NR and DN bacteria than that for heterotrophic bacteria, and greater for contaminated sites than the $\mathrm{CV}$ for the uncontaminated sites. The different treatments (e.g. nitrate, hay) added to the enclosures may have contributed to spatial variation among enclosures. Since no subsamples were taken from within individual enclosures, we do not know the degree of variation at a smaller scale within enclosures.

The G7 and LF sites were irrigated resulting in increased soil moisture and the concentration of oxygen in those sites was expected to be low or even anaerobic conditions created. In fact, higher moisture was associated with greater heterotrophic and NR and DN abundance but the effect was slight. The amount of oxygen available in hydrocarbon contaminated soils determines the pathway by which those contaminates are degraded. For example, the biodegradation of PAHs has been studied under both aerobic and anaerobic conditions. The biotransformation of pollutants by microbial communities has been observed under anaerobic conditions (Coates et al., 1996a, 1996b). Our results showed that although moisture levels varied (range 11.6-37.2\%) among sites and among sampling dates, MPN values for NR and DN bacteria did not vary greatly. However, a different study showed that high soil moisture $(29.76 \% \pm 3.75)$, organic matter, and available nitrogen increased denitrifyer populations (Peralta et al., 2010). In addition, it was shown that phylogenetic composition of the archaeal and bacterial community and nitrogen cy- 
cling functional genes (e.g. nirS and nosZ) were tightly coupled with soil moisture and with seasonal alterations in labile carbon and nitrogen pools where nir $\mathrm{S}$ was more abundant at higher moisture levels (Rasche et al., 2010).

Support for the effect of environmental parameters such as nitrate was shown by the higher nitrate level in J6-F that was accompanied with higher net NR and DN bacteria and \% NR and DN bacteria in J6-F. Other comparisons are suggestive (e.g. higher net $\mathrm{NR}$ and $\mathrm{DN}$ bacteria and $\% \mathrm{NR}$ and $\mathrm{DN}$ bacteria in G5 than in G5P March 2005) but measurements showing a higher nitrate level in G5 than in G5P were obtained in 2003, none were made in March 2005. The amount of nitrate in soil (Tiedje, 1988) and soil moisture (Xia et al., 2004) are well-known to be important regulators of denitrification. It was shown that a higher nitrate concentration in soil indicates a higher denitrification activity (Yu et al., 2012). In addition, soil moisture was identified as an important factor that increased denitrification activity (Orr et al., 2007). The study of denitrification in a tallgrass prairie in central Kansas (Groffman et al., 1993) emphasized that when multiple factors occur simultaneously, denitrification is promoted. These factors are high levels of water, nitrate, and available carbon source (Groffman et al., 1993). However, in this study, nitrate was applied only one time, the easily degraded hydrocarbon may have been already depleted, and moisture levels were generally low. Therefore, the stimulation efforts may not have been successful since not all factors required for denitrification were provided simultaneously. In addition, we are measuring the abundance of NR and DN bacteria. It may take a longer period of favorable conditions to increase the number of DN cells than to stimulate expression of denitrification.

A different study on the effect of environmental factors on denitrification of saline wetlands in semi-arid regions showed that a high exchangeable sodium percentage decreased the denitrification rate, apart from organic carbon, nitrate, and denitrifying bacteria (Huibin et al., 2012). Another study investigated the processes that inhibited the decomposition of organic material and affected the dynamics of mineral nitrogen (Dendooven et al., 2010). Dendooven et al. (2010) found that the high electric conductivity and $\mathrm{pH}$ of alkaline soil inhibited the decomposition of organic materials such as glucose. Also, the authors found that the reduction of nitrate and the formation of nitrite and ammonia in the glucose-amended alkaline soil was a result of aerobic assimilatory nitrate reduction (Dendooven et al., 2010), not dissimilatory nitrate reduction. However, our MPN results show that brine-contaminated sites did not have a lower abundance of NR and DN bacteria. A previous study showed a decrease in the range of organisms that degrade most lowmolecular-weight components of mineral oil with increasing salinity (Kleinsteuber et al., 2006).

This study provides an overview of the effect of several environmental factors such as hay and nitrate-containing fertilizer on the abundance of NR and DN bacteria in these soils. In fact, hay and fertilizer were shown to improve soil fertility while increasing the rate of salt leaching from the soil (Harris et al., 2005). However, the excessive use of fertilizer may increase salinity in arable soils (Quantin et al., 2008). We showed that in some cases, hay only, fertilizer only, or the interaction between hay and fertilizer were associated with lower abundance of NR and DN bacteria. This suggests that the carbon source provided (e.g. hay) may have increased the abundance of other groups of bacteria and/or fungi which, as a result of competition, decreased the relative abundance of NR and DN bacteria. Since the amendments (e.g. hay and/or fertilizer) were associated with a greater abundance of NR and DN bacteria in some cases and lower in other cases, there was no conclusion about the effect of these amendments on the abundance of NR and DN bacteria. However, our results showed that sites that were contaminated 5-10 years previously by crude oil and/or brine did not have a lower abundance of NR and DN bacteria, therefore, the biological potential for denitrification was present despite residual contamination.

\section{Acknowledgments}

We thank Jody Davis and Duane Wolf (University of Arkansas) for assistance in the field and in the laboratory. Funding was provided by the U.S. Environmental Protection Agency Grant Number R830633C009.

\section{References}

Al-Bashir B, T Cseh,, R Leduc, and R Samson (1990) Effect of soil/ contaminant interactions on the biodegradation of naphthalene in flooded soils under denitrifying conditions. Applied Microbiology and Biotechnology 34: 414-419.

Atlas RM (1993) Handbook of microbiological media. CRC Press, Inc. Boca Raton, Florida.

Baron EJ and SM Finegold (1990) Bailey and Scott's Diagnostic Microbiology. 8th Edn., CV Mosby Co., St. Louis, USA., pp. 286-402, 435-438.

Bollmann A and R Conrad (1998) Influence of O2 availability on NO and $\mathrm{N} 2 \mathrm{O}$ release by nitrification and denitrification in soils. Global Change Biology 4: 387-396.

Chèneby D, D Bru, N Pascault, PA Maron, L Ranjard, and L Philippot (2010) Role of plant residues in determining temporal patterns of the activity, size, and structure of nitrate reducer communities in soil. Applied and Environmental Microbiology 76: 7136-7143.

Coates JD, RT Anderson, and DR Lovley (1996a) Oxidation of polycyclic aromatic hydrocarbons under sulfate-reducing conditions. Applied and Environmental Microbiology 62: 1099-1101.

Coates JD, RT Anderson, JC Woodward, EJP Phillips, and DR Lovley (1996b) Anaerobic hydrocarbon degradation in petroleum contaminated harbor sediments under sulfate-reducing and artificially imposed iron-reducing conditions. Environmental Science and Technology 30: 2764-2769.

Dendooven L, RJ Alcántara-Hernández, C Valenzuela-Encinas, M Luna-Guido, F Perez-Guevara, and R Marsch (2010) Dynamics of carbon and nitrogen in an extreme alkaline saline soil: A review. Soil Biology and Biochemistry 42: 865-877.

Dunn NW and IC Gunsalus (1973) Transmissible plasmid coding early enzymes of naphthalene oxidation in Pseudomonas putida. Journal of Bacteriology 114: 974-979.

Duncan K, E Jennings, S Hettenbach, W Potter, K Sublette, G Subramaniam, and R Narasimhan (1998) Nitrogen cycling and nitric oxide emissions in oil-impacted prairie soils. Bioremediation Journal 1: 195-208. 
Duncan KE, R Kolhatkar, G Subramaniam, R Narasimhan, E Jennings, S Hettenbach, A Brown, C McComas, W Potter, and K Sublette (1999) Microbial dynamics in oil-impacted prairie soil. Applied Biochemistry and Biotechnology 77-79: 421-434.

Groffman PM, CW Rice, and JM Tiedje (1993) Denitrification in a tallgrass prairie landscape. Ecology 74: 855-862.

Harms TK, EA Wentz, and NB Grimm (2009) Spatial heterogeneity of denitrification in semi-arid floodplains. Ecosystems 12: 129143.

Harris RF (1981) Effect of water potential on microbial growth and activity. In: JF Parr, WR Gardner, and LF Elliott (eds.) Water Potential Relations in Soil Microbiology: Soil Science Society of America, Madison, pp. 23-95.

Harris TM (1998) Brine impacted soils, remediation. In: RA Meyers (eds.) Encyclopedia of environmental analysis and remediation: New York, John Wiley and Sons, pp. 823-829.

Harris TM, JB Tapp, and KL Sublette (2005) Remediation of oilfield brine-impacted soil using a subsurface drainage system and hay. Environmental Geosciences 12: 101-113.

Jones RA, MW Broder, and G Stotzky (1991) Effects of genetically engineered microorganisms on nitrogen transformations and nitrogentransforming microbial populations in soil. Applied and Environmental Microbiology 57: 3212-3219.

Kennedy AC and KL Smith (1995) Soil microbial diversity and the sustainability of agricultural soil. Plant and Soil 170: 75-86.

Kleinsteuber S, V Riis, I Fetzer, H Harms, and S Müller (2006) Population dynamics within a microbial consortium during growth on diesel fuel in saline environments. Applied and Environmental Microbiology 72: 3531-3542.

Lynch JM and JM Whipps (1990) Substrate flow in the rhizosphere. Plant and Soil 129: 1-10.

Martin K, LL Parsons, RE Murray, and MS Smith (1988) Dynamics of soil denitrifier populations: relationships between enzyme activity, most-probable-number counts, and actual $\mathrm{N}$ gas loss. Applied and Environmental Microbiology 54: 2711-2716.

Murray RE, YS Feig, and JM Tiedje (1995) Spatial heterogeneity in the distribution of denitrifying bacteria associated with denitrification activity zones. Applied and Environmental Microbiology 61: 2791-2793.

Naumova RP, S Selivanovskaia, and IE Cherepneva (1988) Transformation of 2,4,6-trinitrotoluene during oxygen and nitrate respiration in Pseudomonas fluorescens. Prikladnaya Biokhimiya i Microbiologiya 24: 493-498.

Orr CH, EH Stanley, KA Wilson, and JC Finlay (2007) Effects of restoration and reflooding on soil denitrification in a leveed Midwestern floodplain. Ecological Applications 17: 2365-2376.

Paul EA and FE Clark (1989) Reduction and transport of nitrate. In: Soil Microbiology and Biochemistry. Vol. 9. Academic Press, New York, pp. 81-85.

Peralta AL, JW Matthews, and AD Kent (2010) Microbial community structure and denitrification in a wetland mitigation bank. Applied and Environmental Microbiology 76: 4207-4215.

Pope DF and JE Matthews (1993) Bioremediation Using the Land Treatment Concept, EPA/600/R-93/164, Robert S. Kerr Environmental Research Laboratory, Ada, OK.

Quantin C, O Grunberger, N Suvannang, and E Bourdon (2008) Land Management Effects on Biogeochemical Functioning of Salt-Affected Paddy Soils. Pedosphere 18: 183-194.

Rasche F, D Knapp, C Kaiser, M Koranda, B Kitzler, S Zechmeister-
Boltenstern, A Richter, and A Sessitsch (2010) Seasonality and resource availability control bacterial and archaeal communities in soils of a temperate beech forest. International Society for Microbial Ecology Journal 5: 389-402.

Rockne KJ, JC Chee-Sanford, RA Sanford, BP Hedlund, JT Staley, and SE Strand (2000) Anaerobic naphthalene degradation by microbial pure cultures under nitrate-reducing conditions. Applied and Environmental Microbiology 66: 1595-1601.

Rockne KJ and SE Strand (1998) Biodegradation of bicyclic and polycyclic aromatic hydrocarbons in anaerobic enrichments. Environmental Science and Technology 32: 2962-2967.

Rodina AG (1972) Methods in aquatic microbiology. University Park Press, Baltimore, Md, pp. 461.

Sharak Genthner BR, GT Townsend, SE Lantz, and JG Mueller (1997) Persistence of polycyclic aromatic hydrocarbon components of creosote under anaerobic enrichment conditions. Archives of Environmental Contamination and Toxicology 32: 99-105.

Sikkema, J, J de Bont, and B Poolman (1995) Mechanisms of membrane toxicity of hydrocarbons. Microbiological reviews 59: 201222.

Smibert RM and NR Krieg (1994) Phenotypic characterization. In: P Gerhardt, RGE Murray, WA Wood, and N Krieg (eds.) Methods for General and Molecular Bacteriology, American Society for Microbiology, pp. 649.

Sublette K, E Jennings, C Mehta, K Duncan, J Brokaw, T Todd, and G Thoma (2007a) Monitoring soil ecosystem recovery following bioremediation of a terrestrial crude oil spill with and without a fertilizer amendment. Soil and Sediment Contamination 16: 181-208.

Sublette KL, A Moralwar, LP Ford, K Duncan, G Thoma, and J Brokaw (2005) Remediation of a spill of crude oil and brine without gypsum. Environmental Geosciences 12: 115-125.

Sublette KL, JB Tapp, JB Fisher, E Jennings, K Duncan, G Thoma, J Brokaw, and T Todd (2007b) Lessons learned in remediation and restoration in the Oklahoma Prairie: A review. Applied Geochemistry 22: $2225-2239$.

Sublette KL, GJ Thoma, KE Duncan, DC Wolf, and T Todd (2004) Use of Earthworms to Accelerate the Restoration of Oil and Brine Impacted Sites. Final Report for EPA R830633C009.

Tiedje JM (1988) Ecology of denitrification and dissimilatory nitrate reduction to ammonium. In: AJB Zehnder (eds.) Biology of Anaerobic Microorganisms. Wiley, New York, pp. 179-244.

White DC, HC Pinkart, and DB Ringelberg (1997) Biomass measurements: Biochemical approaches. In: CJ Hurst, GR Knudsen, MJ McInerney, LD Stetzenbach, and MV Walter (eds.) Manual of environmental microbiology: Washington, D.C., ASM Press, pp. 91-101.

Wollum AG (1982) Cultural Methods for Soil Microorganisms. In: AL Page (eds.) Methods of Soil Analysis. Part 2. Agron. Monogr. 9. ASA and SSSA, Madison, WI, pp. 790.

Xia X, Z Yang, G Huang, X Zhang, H Yu, and X Rong (2004) Nitrification in natural waters with high suspended-solid content-a study for the Yellow River. Chemosphere 57: 1017-1029.

Yao H, Z He, MJ Wilson, and CD Campbell (2000) Microbial biomass and community structure in a sequence of soils with increasing fertility and changing land use. Microbial Ecology 40: 223-237.

45. Yu H, Y Song, B Xi, E Du, X He, and X Tu (2012) Denitrification potential and its correlation to physico-chemical and biological characteristics of saline wetland soils in semi-arid regions. Chemosphere 89: 1339-1346. 